\title{
Impact of COVID-19 Pandemic on Emergency Inpatient Volume at a Tertiary Eye Care Center in Germany with Corneal Main Specialization Auswirkungen der COVID-19-Pandemie auf das stationäre Notfall-
aufkommen in einem tertiären Augenzentrum in Deutschland
mit der Hauptspezialisierung auf Hornhauterkrankungen
}

Authors

Gábor Tóth ${ }^{1,2,3}{ }^{\mathbb{D}}$, Kassandra Xanthopoulou ${ }^{1}$, Tanja Stachon ${ }^{2}$, János Németh ${ }^{3}$, Réka Hécz ${ }^{4}$, Barbara Berkó-Göttel ${ }^{5}$, Thorsten Pfuhl ${ }^{5}$, Sigrun Smola ${ }^{5}$, Berthold Seitz ${ }^{1 * \mathbb{D}}$, Nóra Szentmáry ${ }^{2,3 *}$

Affiliations

1 Department of Ophthalmology, Saarland University Medical Center, UKS, Homburg/Saar, Germany

2 Dr. Rolf M. Schwiete Center for Limbal Stem Cell and Congenital Aniridia Research, Saarland University, Homburg/Saar, Germany

3 Department of Ophthalmology, Semmelweis University, Budapest, Hungary

4 Pulmonology Hospital, Törökbálint, Hungary

5 Institute of Virology, Saarland University Medical Center, Homburg/Saar, Germany

Key words

COVID-19, pandemic, coronavirus, patient turnover

Schlüsselwörter

COVID-19, Pandemie, Coronavirus, Patientenfluktuation

$\begin{array}{ll}\text { received } & 31.7 .2020 \\ \text { accepted } & 6.11 .2020 \\ \text { published online } & 17.3 .2021\end{array}$

\section{Bibliography}

Klin Monatsbl Augenheilkd 2021; 238: 715-720

DOI 10.1055/a-1327-3393

ISSN 0023-2165

(c) 2021. Thieme. All rights reserved. Georg Thieme Verlag KG, Rüdigerstraße 14, 70469 Stuttgart, Germany
Correspondence

Dr. Gábor Tóth MD, FEBO

Saarland University Medical Center,

Department of Ophthalmology

Kirrberger Straße 100, 66421 Homburg/Saar, Germany

Phone: + 36208258559 , Fax: + 4968411622479

gabortothgabor@gmail.com

\section{ABSTRACT}

Background To estimate the impact of the COVID-19 pandemic on emergency inpatient volume in a tertiary eye care center in Germany with corneal main subspecialization.

Material and Methods A retrospective review of ocular emergency patients who attended the inpatient unit of the Department of Ophthalmology of Saarland University, Homburg/Saar, Germany during the COVID-19 pandemic, between 1 March and 30 April 2020, in comparison to the same time period in 2019. For each subject, clinical history and surgical reports were reviewed. After 24 March 2020, PCR examinations for SARS-CoV-2 were performed from throat swab specimens in all patients using real-time RT-PCR.

Results Totally, 135 patients were admitted in 2019 and 115 patients in 2020 as emergency cases. The patient age at the time of admission did not differ significantly between the two time periods $(63.6 \pm 17.9$ years vs. $62.5 \pm 19.6$ years) $(p=0.792)$, but the average length of hospital stays increased significantly for $2020(4.0 \pm 3.6$ vs. $4.4 \pm 2.7$ days, $p=0.043)$. The percentage of admissions due to acute corneal hydrops (0\% vs. 3.5\%) increased significantly from 2019 to 2020 $\left(x^{2}=4.772, p=0.028\right)$, however, there was not a significant difference between the two years for any other diagnosis $\left(x^{2} \leq 3.564, p \geq 0.059\right)$. From 2019 to 2020, the percentage of acute intravitreal anti-VEGF injections decreased significantly $\left(7.9 \%\right.$ vs. $\left.1.3 \%, X^{2}=3.985, p=0.045\right)$, but the proportion of other emergency surgeries did not differ between the two years ( $\left.x^{2} \leq 3.617, p \geq 0.057\right)$. COVID-19 PCR examination

Shared senior authorships. 
was performed in 66 (57.4\%) cases in 2020 and all samples (100\%) were negative.

Conclusions The COVID pandemic did not change emergency inpatient volume in our department, but duration of hospital stay was extended on average by 8 hours, mainly due to additional COVID-19-PCR examinations. The proportion of the most frequently performed surgeries did not change remarkably between 2019 and 2020, but with the introduction of Muraine's sutures in 2019, the percentage of admissions with acute corneal hydrops (with or without subsequent surgery) increased for 2020. No urgent surgery had to be postponed due to the COVID-19 pandemic at our department; all operations were performed successfully.

\section{ZUSAMMENFASSUNG}

Ziel Abschätzung der Auswirkungen der COVID-19-Pandemie auf das stationäre Notfallvolumen in einem tertiären Augenzentrum in Deutschland mit Spezialisierung auf korneale Erkrankungen.

Methoden Eine retrospektive Übersicht über okuläre Notfallpatienten, die während der COVID-19-Pandemie zwischen dem 1. März und 30. April 2020 auf der stationären Abteilung der Klinik für Augenheilkunde des Universitätsklinikums des Saarlandes, Homburg/Saar, Deutschland, behandelt wurden, im Vergleich zum gleichen Zeitraum im Jahr 2019. Für jeden Patienten wurden die Anamnese und die Operationsberichte überprüft. Nach dem 24. März 2020 wurden bei allen Patienten PCR-Untersuchungen für SARS-CoV-2 aus Rachenabstrichproben mittels Real-Time-PCR durchgeführt.

Ergebnisse Insgesamt wurden im Jahr 2019135 Patienten und im Jahr 2020115 Patienten als Notfälle in der Klinik für Augenheilkunde aufgenommen. Das Patientenalter zum Zeit- punkt der Aufnahme unterschied sich zwischen beiden Zeiträumen nicht signifikant $(63,6 \pm 17,9$ Jahre vs. $62,5 \pm 19$, 6 Jahre) $(p=0,792)$, die durchschnittliche Dauer des Krankenhausaufenthalts nahm jedoch 2020 im entsprechenden Zeitraum signifikant zu (4,0 $\pm 3,6$ vs. 4,4 $\pm 2,7$ Tage; $p=0,043)$. Der Prozentsatz der Einweisungen aufgrund eines akuten Hornhauthydrops (0 vs. 3,5\%) stieg 2020 im Vergleich zum Vorjahreszeitraum signifikant an $\left(x^{2}=4,772 ; p=0,028\right)$, der Prozentsatz aller anderen Diagnosen unterschied sich jedoch zwischen beiden Jahren nicht signifikant $\left(x^{2} \leq 3,564\right.$; $\left.p \geq 0,059\right)$. Der Prozentsatz der akuten intravitrealen Anti-VEGF-Injektionen war 2020 signifikant geringer als im entsprechenden Zeitraum 2019 (7,9 vs. 1,3\%; $\left.x^{2}=3,985 ; p=0,045\right)$, der Anteil aller anderen Notfalloperationen unterschied sich zwischen beiden Jahren nicht signifikant $\left(X^{2} \leq 3,617 ; p \geq 0,057\right)$. Die SARS-CoV-2-PCR-Untersuchung wurde 2020 in 66 (57,4\%) Fällen durchgeführt, wobei alle Proben (100\%) negativ getestet wurden.

Schlussfolgerungen Durch die COVID-19-Pandemie wurde die Anzahl der stationären Notfallpatienten in unserer Abteilung nicht verändert, jedoch verlängerte sich die Dauer des Krankenhausaufenthalts im Durchschnitt um 8 Stunden, was im Wesentlichen auf die zusätzliche SARS-CoV-2-PCR-Untersuchung zurückzuführen ist. Der Anteil der am häufigsten durchgeführten Operationen hat sich zwischen 2019 und 2020 nicht wesentlich verändert, jedoch stieg der Prozentsatz der Einweisungen mit akutem Hornhauthydrops (allerdings ohne Anstieg nachfolgender Operationen), was auf die Einführung von Muraine-Nähten im Jahr 2019 zurückzuführen ist. In unserer Abteilung musste keine dringende Operation aufgrund der COVID-19-Pandemie verschoben werden, alle notwendigen Operationen wurden erfolgreich durchgeführt.

\section{Introduction}

A new infectious disease that can affect airways and lungs was observed for the first time by Li Wenliang, a Chinese ophthalmologist, among his patients with viral conjunctivitis in Wuhan, China in December 2019 [1]. The World Health Organization (WHO) published a report about a pneumonia with an unknown origin observed in Wuhan on 5 January 2020. Since then, Coronavirus disease 2019 (COVID-19) caused by SARS-CoV-2 became a significant public health problem and was even declared a pandemic by the WHO on 11 March 2020 [2].

More than 17 million people have been infected in the world with COVID-19 up to this day [3]. The infection is potentially fatal, with a $0.5-1 \%$ mortality rate in Germany [4]. About $12 \%$ of patients with COVID-19 need intensive care and $75 \%$ of those require mechanical ventilation $[5,6]$.

On 27 January, the first confirmed cases of COVID-19 were reported in Germany. On 30 July, the number of confirmed cases exceeded 209000, and more than 9100 people have died from the infection in our country [3].
In order to limit the spread of the pandemic, most governments as well as international and national ophthalmologic societies recommended or even ordered the cancellation and postponement of all treatments other than urgent or emergent care [7].

Plenty of articles have been published about COVID-19 as yet, but there is no reported information about the impact of the COVID-19 pandemic on ophthalmic eye care, especially on emergency patient volume and turnover in an ophthalmic inpatient unit.

The primary aim of this study was to assess the impact of the COVID-19 pandemic on emergency inpatient volume in a tertiary eye care center in Germany.

\section{Material and Methods}

This retrospective study was undertaken at a tertiary eye care center to analyze the impact of the COVID-19 pandemic on patient volume and turnover in an inpatient unit in Germany.

In this retrospective review, all ocular emergencies attending the inpatient unit of the Department of Ophthalmology, Saarland 
University Medical Center, Homburg/Saar, Germany during the COVID-19 pandemic between 1 March and 30 April 2020 were compared to the same time period in 2019. The study was performed in accordance with the Declaration of Helsinki Guidelines for Human Research.

For each subject, clinical data were reviewed including patient demographics, clinical history and diagnosis, type of surgery, and results of the COVID-19 PCR tests.

Following 24 March 2020, PCR examinations for SARS-CoV-2 were performed from throat swab specimens in all patients by single sample testing using dual target real-time PCR tests (either SARS-CoV-2 RT-PCR Kit 1.0 RUO, Altona Diagnostics GmbH, Hamburg, Germany, [8,9] or Cobas SARS-CoV-2, Roche Diagnostics $\mathrm{GmbH}$, Mannheim, Germany) for all inpatients in our hospital through the Institute of Virology, Saarland University Medical Center.

Statistical analysis was performed using IBM SPSS Statistics for Windows, Version 19.0 (IBM Corp., Armonk, NY, USA). The percentage of primary ophthalmic diseases (cause of emergency admission) and performed surgeries have been compared between the two time periods using the chi-square test. To compare patient age and length of hospital stay during the two time periods, the Student's t-test was used following testing normal distribution. The nonparametric Mann-Whitney $U$ test was used for nonnormally distributed variables. A p value $<0.05$ was considered statistically significant.

\section{Results}

In total, 135 patients were admitted as emergencies in 2019 and 115 patients in 2020. There were 77 (57.0\%) males and 58 (43.0\%) females in 2019 and 66 (57.4\%) males and 49 (42.6\%) females in the 2020 study population. The patient age at the time of the admission did not differ significantly between patients in 2019 and 2020 [63.6 \pm 17.9 (range 3 to 90 ) years vs. $62.5 \pm 19.6$ (range 8 to 92 ) years] $(p=0.792)$. COVID-19 PCR examinations were performed in 66 (57.4\%) cases only in 2020 and all samples (100\%) were negative.

The average length of hospital stay was significantly higher in 2020 ( $4.4 \pm 2.7$ days) than in $2019(4.0 \pm 3.6$ days) $(p=0.043)$.

From the first to the second analyzed time period, percentage of acute corneal hydrops ( $0 \%$ vs. $3.5 \%$ ) was significantly higher $\left(X^{2}=4.772, p=0.028\right)(\triangleright$ Table 1$)$. The percentage of corneal ulcers $\left(22.2 \%\right.$ vs. $\left.20.0 \%, x^{2}=0.183, p=0.668\right)$, glaucoma $(9.6 \%$ vs. $\left.15.7 \%, x^{2}=2.073, p=0.149\right)$, rhegmatogenous retinal detachment $\left(17.0 \%\right.$ vs. $\left.10.4 \%, x^{2}=2.248, p=0.133\right)$, erosion on the corneal graft ( $5.9 \%$ vs. $\left.8.7 \%, x^{2}=0.713, p=0.398\right)$, corneal graft rejection (3.7\% vs. $\left.7.8 \%, x^{2}=1.996, p=0.157\right)$, and other diagnoses $\left(x^{2} \leq 3.564, p \geq 0.059\right)$ did not change significantly between admitted patients in 2019 and 2020.

Comparing the first to the second analyzed time period, the percentage of acute intravitreal anti-VEGF injections (e.g., due to cystoid macular edema due to retinal vein occlusion) (7.9\% vs. $1.3 \%)$ decreased significantly $\left(x^{2}=3.985, p=0.045\right)(\triangleright$ Table 2$)$. The percentage of vitrectomies $\left(32.6 \%\right.$ vs. $29.9 \%, X^{2}=0.214$, $p=0.643)$, emergency penetrating keratoplasties (PKP) $(14.6 \%$ vs. $\left.15.6 \%, X^{2}=0.013, p=0.907\right)$, amniotic membrane transplan-
- Table 1 Primary ophthalmic diseases of patients who attended the inpatient unit of the Department of Ophthalmology Saarland University Medical Center (Homburg/Saar, Germany) between 1 March and 30 April 2019 (115 patients) and between 1 March and 30 April 2020 (135 patients) as emergency cases. The chi-square test was performed to compare the percentages between both years; a significant $p$ value is displayed bold.

\begin{tabular}{|c|c|c|c|}
\hline & $\begin{array}{l}2019 \\
\text { n (\%) }\end{array}$ & $\begin{array}{l}2020 \\
\text { n (\%) }\end{array}$ & $x^{2} ; p$ \\
\hline Corneal ulcer & $30(22.2)$ & $23(20.0)$ & $0.183 ; 0.668$ \\
\hline Glaucoma & $13(9.6)$ & $18(15.7)$ & $2.073 ; 0.149$ \\
\hline $\begin{array}{l}\text { Rhegmatogenous retinal } \\
\text { detachment }\end{array}$ & $23(17.0)$ & $12(10.4)$ & $2.248 ; 0.133$ \\
\hline $\begin{array}{l}\text { Erosion on the corneal } \\
\text { graft }\end{array}$ & $8(5.9)$ & $10(8.7)$ & $0.713 ; 0.398$ \\
\hline Graft rejection & $5(3.7)$ & $9(7.8)$ & $1.996 ; 0.157$ \\
\hline Retinal arterial occlusion & $5(3.7)$ & $6(5.2)$ & $0.338 ; 0.560$ \\
\hline Retinal vein occlusion & $6(4.4)$ & $5(4.3)$ & $0.001 ; 0.970$ \\
\hline $\begin{array}{l}\text { Acute corneal hydrops in } \\
\text { keratoconus }\end{array}$ & $0(0)$ & $4(3.5)$ & $4.772 ; 0.028$ \\
\hline $\begin{array}{l}\text { Failed primary DMEK } \\
\text { graft }\end{array}$ & $6(4.4)$ & $4(3.5)$ & $0.151 ; 0.697$ \\
\hline Endophthalmitis & $3(2.2)$ & $3(2.6)$ & $0.039 ; 0.842$ \\
\hline Trauma & $8(5.9)$ & $3(2.6)$ & $1.624 ; 0.202$ \\
\hline $\begin{array}{l}\text { Complication during } \\
\text { cataract surgery }\end{array}$ & $0(0)$ & $3(2.6)$ & $3.564 ; 0.059$ \\
\hline $\begin{array}{l}\text { Anterior/posterior } \\
\text { ischemic optic } \\
\text { neuropathy }\end{array}$ & $7(5.2)$ & $3(2.6)$ & $1.073 ; 0.300$ \\
\hline Endothelitiis & $1(0.7)$ & $2(1.7)$ & $0.522 ; 0.469$ \\
\hline Vitreous hemorrhage & $1(0.7)$ & $2(1.7)$ & $0.522 ; 0.469$ \\
\hline Submacular bleeding & $5(3.7)$ & $2(1.7)$ & $0.880 ; 0.348$ \\
\hline $\begin{array}{l}\text { Crystalline lens/intraoc- } \\
\text { ular lens dislocation }\end{array}$ & $1(0.7)$ & $2(1.7)$ & $0.522 ; 0.469$ \\
\hline Vitreous prolapse & $1(0.7)$ & $1(0.9)$ & $0.013 ; 0.909$ \\
\hline $\begin{array}{l}\text { Limbal stem cell } \\
\text { deficiency }\end{array}$ & $0(0)$ & $1(0.9)$ & $1.178 ; 0.277$ \\
\hline Optic neuritis & $2(1.5)$ & $1(0.9)$ & $0.196 ; 0.657$ \\
\hline Retinal vasculitis & $0(0)$ & $1(0.9)$ & $1.178 ; 0.277$ \\
\hline Dacryocystitis & $4(3.0)$ & $0(0)$ & $3.462 ; 0.062$ \\
\hline Preseptal cellulitis & $2(1.5)$ & $0(0)$ & $1.717 ; 0.190$ \\
\hline $\begin{array}{l}\text { Ocular ischemic } \\
\text { syndrome }\end{array}$ & $1(0.7)$ & $0(0)$ & $0.855 ; 0.355$ \\
\hline $\begin{array}{l}\text { Complication after eye } \\
\text { lid surgery }\end{array}$ & $1(0.7)$ & $0(0)$ & $0.855 ; 0.355$ \\
\hline $\begin{array}{l}\text { Terrien's marginal } \\
\text { degeneration }\end{array}$ & $1(0.7)$ & $0(0)$ & $0.855 ; 0.355$ \\
\hline Scleritis & $1(0.7)$ & $0(0)$ & $0.855 ; 0.355$ \\
\hline $\begin{array}{l}\text { Total number of } \\
\text { patients }\end{array}$ & $135(100)$ & $115(100)$ & \\
\hline
\end{tabular}


- Table 2 Emergency ophthalmic surgeries of patients who attended the inpatient unit of the Department of Ophthalmology Saarland University Medical Center (Homburg/Saar, Germany) between 1 March and 30 April 2019 (89 patients) and between 1 March and 30 April 2020 (77 patients). The chi-square test was performed to compare the percentages between both years; a significant $\mathrm{p}$ value is displayed bold.

\begin{tabular}{|c|c|c|c|}
\hline & $\begin{array}{l}2019 \\
\text { n (\%) }\end{array}$ & $\begin{array}{l}2020 \\
\text { n (\%) }\end{array}$ & $x^{2} ; p$ \\
\hline Vitrectomy & $29(32.6)$ & $23(29.9)$ & $0.214 ; 0.643$ \\
\hline Penetrating keratoplasty & $13(14.6)$ & $12(15.6)$ & $0.013 ; 0.907$ \\
\hline $\begin{array}{l}\text { Amniotic membrane } \\
\text { transplantation }\end{array}$ & $4(4.5)$ & $8(10.4)$ & $2.012 ; 0.156$ \\
\hline Cyclophotocoagulation & $4(4.5)$ & $7(9.1)$ & $1.313 ; 0.251$ \\
\hline $\begin{array}{l}\text { Intracameral steroid } \\
\text { injection }\end{array}$ & $6(6.7)$ & $6(7.8)$ & $0.048 ; 0.825$ \\
\hline Anterior chamber lavage & $4(4.5)$ & $5(6.5)$ & $0.283 ; 0.594$ \\
\hline Rebubbling after DMEK & $6(6.7)$ & $4(5.2)$ & $0.204 ; 0.651$ \\
\hline Corneal abrasion & $2(2.2)$ & $3(3.9)$ & $0.352 ; 0.552$ \\
\hline Muraine sutures & $0(0)$ & $3(3.9)$ & $3.450 ; 0.063$ \\
\hline $\begin{array}{l}\text { Neodynium:YAG laser } \\
\text { iridotomy }\end{array}$ & $2(2.2)$ & $3(3.9)$ & $0.352 ; 0.552$ \\
\hline Additional PKP sutures & $2(2.2)$ & $2(2.6)$ & $0.015 ; 0.900$ \\
\hline Retinal cryotherapy & $2(2.2)$ & $2(2.6)$ & $0.015 ; 0.900$ \\
\hline $\begin{array}{l}\text { Intraocular lens } \\
\text { reposition/exchange }\end{array}$ & $1(1.1)$ & $1(1.3)$ & $0.007 ; 0.930$ \\
\hline Cataract surgery & $1(1.1)$ & $1(1.3)$ & $0.007 ; 0.930$ \\
\hline Corneal wound closure & $1(1.1)$ & $1(1.3)$ & $0.007 ; 0.930$ \\
\hline $\begin{array}{l}\text { Intravitreal anti-VEGF } \\
\text { injection }\end{array}$ & $7(7.9)$ & $1(1.3)$ & $3.985 ; 0.045$ \\
\hline Lens cortex removal & $0(0)$ & $1(1.3)$ & $1.137 ; 0.286$ \\
\hline Anterior vitrectomy & $0(0)$ & $1(1.3)$ & $1.137 ; 0.286$ \\
\hline Eyelid surgery & $4(4.5)$ & $0(0)$ & $3.617 ; 0.057$ \\
\hline Temporal artery biopsy & $3(3.4)$ & $0(0)$ & $2.697 ; 0.100$ \\
\hline $\begin{array}{l}\text { Subretinal injection of } \\
\text { tissue plasminogen } \\
\text { activator }\end{array}$ & $2(2.2)$ & $0(0)$ & $1.788 ; 0.181$ \\
\hline Iris reconstruction & $1(1.1)$ & $0(0)$ & $0.889 ; 0.345$ \\
\hline Scleral buckling surgery & $1(1.1)$ & $0(0)$ & $0.889 ; 0.345$ \\
\hline $\begin{array}{l}\text { Total number of } \\
\text { performed emergency } \\
\text { surgeries }\end{array}$ & 95 (100) & 84 (100) & \\
\hline
\end{tabular}

tations ( $4.5 \%$ vs. $\left.10.4 \%, x^{2}=2.012, p=0.156\right)$, cyclophotocoagulations ( $4.5 \%$ vs. $\left.9.1 \%, x^{2}=1.313, p=0.251\right)$, and other surgeries $\left(x^{2} \leq 3.617, p \geq 0.057\right)$ did not change significantly between 2019 and 2020 .

\section{Discussion}

We analyzed the impact of the COVID-19 pandemic on emergency inpatient care at a tertiary eye care center in Germany. The Department of Ophthalmology, Saarland University Medical
Center is known to be one of the leading corneal centers. To the best of our knowledge, this is the first study to report on the impact of the COVID-19 pandemic on emergency inpatient volume and turnover in an ophthalmic inpatient unit in Germany.

SARS-CoV-2 can cause serious respiratory failure, with fever, dry cough, and dyspnea. Other coronaviruses can cause a variety of eye inflammations in animals (e.g. uveitis, vasculitis, retinitis) [10]. Contrarily, SARS-CoV-2 was reported to cause only moderate conjunctivitis in humans to date, with conjunctival congestion, watery discharge, and follicular reaction. Prevalence of conjunctivitis due to COVID-19 was estimated to be as low as $0.8 \%$ in subjects with COVID-19 infection [11].

In spring 2020, most of the governments introduced strict restrictions and lockdowns in daily life worldwide in order to reduce the transmission of the COVID-19 virus. Due to this reason, the government of Saarland also announced that hospitals and healthcare systems have to reduce the number of elective procedures by $50 \%$ at the end of March. In addition, borders with France and Luxembourg, theaters, restaurants, and schools were closed and special procedure recommendations were introduced. The ophthalmic procedure recommendation listed diseases and cases that required urgent eye examinations and interventions (e.g., eye injuries, sudden loss of vision, endophthalmitis, retinal detachment, acute angle-closure glaucoma, eyelid trauma, open globe injury, emergency keratoplasty).

In view of that, a COVID-19 outbreak at an eye clinic was reported [12] and according to the governmental regulations in Germany, our department also had to cancel and postpone the majority of cataract, eye lid, glaucoma, and elective retinal surgeries for 3-6 months from 6 March 2020. Moreover, from 16 March, all outpatient appointments other than emergency care were postponed up to 3 months in order to decrease the patient volume at our department.

Nevertheless, from 2019 to 2020, only the percentage of the diagnosis acute corneal hydrops (0\% vs. $3.5 \%$ ) increased significantly between acutely admitted patients $\left(x^{2}=4.772, p=0.028\right)$ ( $\vee$ Table 1), but the percentage of admitted corneal ulcers, acute glaucoma subjects, rhegmatogenous retinal detachments, erosion on the corneal graft, corneal graft rejection, and other diagnoses $\left(x^{2} \leq 3.564, p \geq 0.059\right)$ did not change significantly. The increase of admitted acute hydrops patients was suspectedly related to the introduction of Muraine's suture in acute keratoconus is 2019 at our department, which significantly increased the overall number of such admitted patients (with or without subsequent surgery) for 2020. Muraine's suture with intrastromal pre-Descemet's membrane compression sutures associated with intracameral air injection has been proven to be an efficient surgical method to manage acute corneal hydrops in keratoconus [13].

Due to the high risk of visual impairment, none of the intravitreal anti-VEGF injections were postponed (there were all administered timely) from our side for subjects with AMD during the pandemic, if patients dared to come to our IVOM center [14].

Nevertheless, we could observe a significant decrease in the number of urgent intravitreal anti-VEGF injections at the inpatient unit from 2019 to 2020 (7.9\% vs. $\left.1.3 \%, x^{2}=3.985, p=0.045\right)$. This could be explained by generally more difficult accessibility of eye care in Germany due to the pandemic. 
Due to the fluctuation of the availability of corneal donor grafts, no elective PKP was postponed. Moreover, the number of elective PKPs even increased slightly for 2020 (102 vs. 114). It was important to understand that we had to find a medical and ethical balance between inhibition of the spread of the virus and provision of proper eye care service.

Vitrectomy and urgent penetrating keratoplasty were the two most frequently performed urgent ophthalmic interventions in our sample in both 2019 and 2020 and their number and percentage among all urgent surgeries did not differ significantly between both years $\left(x^{2}=0.214, p=0.643\right.$ and $x^{2}=0.013$, $p=0.907)$. Moreover, the total number of other performed urgent surgeries also did not change between 2019 and 2020. We could provide eye care for emergency cases with the adherence of hygienic precautions and no COVID-19 case occurred in our department. Thus, COVID-19 did not have a negative effect on our emergency patient flow.

The protection of patients and medical staff in order to decrease the possibility of virus transmission was crucial. Every resident of Saarland received vouchers for free surgical masks.

Potentially infected colleagues were screened via PCR immediately and all co-workers of the hospital were routinely screened every 2 weeks. Every COVID-19 positive employee was sent to 14-day quarantine. Fortunately, no COVID-19 co-worker was found during the examined period in our department.

A reception was set up at the entrance of our department. A receptionist coordinated the patients with a list of the appointments. Every patient underwent symptom (cough, breathlessness), fever, travel, and contact screening and hand disinfection at the entrance point of the department, and received a surgical mask right at admission, which they had to wear during the hospitalization. COVID-19 swabs were obtained from all patients in house in Homburg at admission and stayed on one of 6 "floating zone" inpatient rooms by themselves until the PCR test result was communicated by our Department of Virology around $6 \mathrm{p}$. m. the same day. Ophthalmologists are a high-risk category due to close contact with patients [15]. Plastic shields were equipped at reception and added to slit lamps and examination devices as a barrier to reduce face-to-face contact and possible contamination. Medical staff wore a surgical mask all day, while regular use of gloves was optional. Both patients and colleagues had to commonly perform hand washing and disinfection. In addition, patients had to keep $1.5 \mathrm{~m}$ distance from other patients. Since $20 \mathrm{March}$, medical and paramedical staff had to wear an FFP2 mask. In our department, FFP3 masks were only used by colleagues who were responsible for COVID-19 tests and for examination of patients with a high suspicion of COVID-19 infection.

According to the University guidelines, between 1 and 23 March, only patients who had typical symptoms or a reasonable suspicion of having COVID-19 were tested by COVID-19 PCR. If a patient was found to be COVID-19 positive, they would be sent home for quarantine. Nevertheless, as there were no COVID-19 PCR positive patients at the Department of Ophthalmology during these 23 days, this never happened.

From 24 March - as every patient was considered already potentially COVID-19 positive - nearly every subject underwent a COVID-19 PCR examination at admission, even if asymptomatic.
Detailed examination and surgery occurred only after proving COVID-19 PCR negativity. PCR for COVID-19 was mostly performed the day before surgery, but in some urgent cases (acute retinal detachment, endophthalmitis, open eye injury, perforated corneal ulcer, intraocular foreign body), the result of the test was sent within 4 hours.

According to our results, during the first month of the COVID19 pandemic, only one COVID-19 patient attended the inpatient unit of our clinic. He was sent home immediately after the positive test was reported and all co-workers in contact were screened by PCR but were all negative.

Nevertheless, we could observe a significant increase, on average, by about 8 hours $(p=0.043)$ for the length of hospital stay of our patients for 2020 compared to 2019 . This may be related to the additional COVID-19 PCR examinations, which had to be performed for all inpatients.

\section{Conclusions}

The COVID pandemic did not change emergency inpatient volume at the Department of Ophthalmology, Saarland University Medical Center, but hospital stays were extended, on average, by 8 hours, mainly due to additional COVID-19-PCR examinations. The proportion of the most frequently performed surgeries did not change markedly between 2019 and 2020, but with the introduction of Muraine's sutures in 2019, the percentage of admissions with acute corneal hydrops (with or without subsequent surgery) increased for 2020. In addition, the percentage of acute intravitreal anti-VEGF injections decreased, probably due to the more difficult overall accessibility of eye care in Germany during the pandemic. No urgent surgery had to be postponed due to the COVID-19 pandemic at our department. All surgeries were performed successfully without contamination of surgeons or anesthetists.

\section{Conflict of Interest}

Dr. Tóth reported grants from EFOP-3.6.3-VEKOP-16-2017-00009. The work of Dr. Szentmáry at the Dr. Rolf M. Schwiete Center was supported by the Dr. Rolf M. Schwiete Foundation. No conflicting relationship exists for remaining authors.

\section{References}

[1] Petersen E, Hui D, Hamer DH et al. Li Wenliang, a face to the frontline healthcare worker. The first doctor to notify the emergence of the SARS-CoV-2, (COVID-19), outbreak. Int J Infect Dis 2020; 93: 205-207

[2] World Health Organization. Coronavirus disease 2019 (COVID-19) Situation Report - 51. Accessed May 26, 2020 at: www.who.int/docs/ default-source/coronaviruse/situation-reports/20200311-sitrep-51covid-19.pdf

[3] John Hopkins University of Medicine. COVID-19 Case Tracker. Accessed July 30, 2020 at: https://coronavirus.jhu.edu/

[4] Salzberger B, Buder F, Lampl B et al. Epidemiology of SARS-CoV-2. Infection 2020. doi:10.1007/s15010-020-01531-3

[5] Phua J, Weng L, Ling $L$ et al. Intensive care management of coronavirus disease 2019 (COVID-19): challenges and recommendations. Lancet Respir Med 2020; 8: 506-517 
[6] Bhatraju PK, Ghassemieh B], Nichols M et al. Covid-19 in Critically III Patients in the Seattle Region - Case Series. N Engl J Med 2020; 382: 2012-2022

[7] American Academy of Ophthalmology. List of urgent and emergent ophthalmic procedures. Accessed May 26, 2020 at: https://www.aao.org/ headline/alert-important-coronavirus-context

[8] Lohse S, Pfuhl T, Berkó-Göttel B et al. Pooling of samples for testing for SARS-CoV-2 in asymptomatic people. Lancet Infect Dis 2020; 20: 1231 1232. doi:10.1016/S1473-3099(20)30362-5

[9] Lohse S, Pfuhl T, Berkó-Göttel B et al. Challenges and issues of SARS-CoV-2 pool testing. Author's reply. Lancet Infect Dis 2020; 20 : 1234-1235. doi:10.1016/S1473-3099(20)30455-2

[10] Seah I, Agrawal R. Can the coronavirus disease 2019 (COVID-19) affect the eye? A review of coronaviruses and ocular implications in humans and animals. Ocul Immunol Inflamm 2020; 28: 391-395
[11] Guan W], Ni ZY, Hu Y et al. Clinical characteristics of coronavirus disease 2019 in China. N Engl J Med 2020; 382: 1708-1720

[12] Jorstad OK, Moe MC, Eriksen K et al. Coronavirus disease 2019 (COVID-19) outbreak at the Department of Ophthalmology, Oslo University Hospital, Norway. Acta Ophthalmol 2020; 98: e388-e389

[13] Yahia Chérif H, Gueudry J, Afriat M et al. Efficacy and safety of pre-Descemet's membrane sutures for the management of acute corneal hydrops in keratoconus. Br J Ophthalmol 2015; 99: 773-777

[14] Abdin AD, Suffo S, Bischoff-Jung $M$ et al. Vorteile eines separierten IVOM-Zentrums an einer deutschen Universitäts-Augenklinik. Ophthalmologe 2020; 117: 50-57

[15] Romano MR, Montericcio A, Montalbano C et al. Facing COVID-19 in ophthalmology department. Curr Eye Res 2020; 45: 653-658 